\title{
Research Article: Studies on agronomic practices to mitigate crop stress in aerobic rice (Oryza sativa) at coastal deltaic areas of Karaikal
}

\section{P. BHUVANASWRI, A.L. NARAYANAN, R. MOHAN AND S. SUNDARAVARATHAN}

Article Chronicle: Received :

10.07.2017;

Accepted :

23.07.2017

KEY Words:

Aerobic rice,

Dates of sowing,

Seed hardening,

Direct, Derived

weather parameters
SUMMARY : A field experiment was conducted at Pandit Jawaharlal Nehru College of Agriculture and Research Institute (PAJANCOA and RI), Karaikal to investigate the performance of seed hardening in aerobic rice at various dates of sowing during Rabi season in the coastal deltaic areas of Karaikal. The treatment combination comprised of four dates of sowing at weekly interval [September $12^{\text {th }}\left(D_{1}\right)$, September $20^{\text {th }}\left(\mathrm{D}_{2}\right)$, September $27^{\text {th }}\left(\mathrm{D}_{3}\right)$ and October $4^{\text {th }}\left(\mathrm{D}_{4}\right)$ ] and three seed hardening techniques [one $\% \mathrm{KCl}\left(\mathrm{H}_{1}\right)$, water $\left(\mathrm{H}_{2}\right)$ and control $\left.\left(\mathrm{H}_{3}\right)\right]$. The treatments were evaluated in factorial concept of RBD and replicated thrice. It was found from the present investigation that growth and yield attributes were higher in early sown crop (September $\left.12^{\text {th }}\right)\left(\mathrm{D}_{1}\right)$ coupled with water hardening $\left(\mathrm{H}_{2}\right)$ technique. Phenophase studies were also conducted for all the treatments. Direct and derived weather parameters were correlated and regressed between grain yield and DMP of aerobic rice during the crop period.

How to cite this article : Bhuvanaswri, P., Narayanan, A.L., Mohan, R. and Sundaravarathan, S. (2017). Studies on agronomic practices to mitigate crop stress in aerobic rice (Oryza sativa) at coastal deltaic areas of Karaikal. Agric. Update, 12(TECHSEAR-2) : 360-364; DOI: 10.15740/HAS/AU/12.TECHSEAR(2)2017/360-364.

\section{Author for correspondence :}

\section{P. BHUVANASWRI,} Agricultural College and Research Institute, (T.N.A.U.), MADURAI (T.N.) INDIA

See end of the article for authors' affiliations 